\title{
The Influence of Covid-19 on Subprime in the U.S.
}

\author{
Haoyang Li \\ University of Southampton, Southampton, UK
}

\begin{abstract}
Subprime lending in the United States was a major concern after the 2008 financial crisis. While Covid-19 is sweeping the world, how will the US government and financial institutions deal with the potential crisis of subprime mortgage will be discussed in this study. Financial market institutions and the US government should both change their strategies to deal with the crisis. In addition to controlling the spread of the epidemic, the US government should temporarily lower the minimum wage and provide a series of quantitative financial subsidies. Financial institutions should also update loan data and use better monitoring and regulation to reduce subprime risk to cope with this potential crisis.
\end{abstract}

\section{Introduction}

Subprime mortgages, as opposed to mortgages that have good credit conditions, loan lenders do not (or do not have sufficient) have income or repayment ability. These lenders are highly likely to default. Because of the rapid development of the financial industry and derivatives, subprime loans in the United States are not limited to the real estate market which is the initial origin leading the financial crisis in 2008. They have expanded to many other industries, such as micro-banking loans and auto markets. Subprime lending is still an unavoidable problem in the development of the American economy. In the case of coVID-19, the US loan market may have a potential crisis. On the evening of 30 January 2020, the World Health Organization (WHO) announced that novel Coronavirus outbreak was listed as a public health emergency of international concern. From January 21st, since the first case was detected in the US, Covid-19 has sweeping through American society. The impact of Covid-19 on economic activity is already clear. As of 6 p.m. Edt on September 14, 2020, there have been 6550629 confirmed cases of COVID-19 and 194,411 deaths reported in the United States. Ohio Governor Mike DeWine said: "We are at war. In wartime, we have to make sacrifices." As Mike said, some states in the United States have declared a state of emergency. Like New York State declared eighteen days of pause. On March 16, Local time, San Francisco announced that the city will be closed from midnight on March 16. Citizens were asked to stay at home. Only public services, such as pharmacies and grocery stores, will remain open. Much economic activity has come to a standstill with shutdowns. This paper analyzes the impact of Covid-19 on the loan market by comparing the data of unemployment rate and outstanding loans of the private sector in the United States. By studying the situation of the US loan market after the outbreak of Covid-19, this paper proposes reasonable suggestions for the government and financial institutions to deal with the crisis that has already happened or may happen. The policy and strategy changes proposed in the paper may play a role in the decision-making of future financial crises caused by a similar situation.

\section{The Connection and Impact of Covid-19 with Subprime lending}

\subsection{Because of Covid-19, states in the US have adopted different lockout policies}

More than 50 million people are now out of work because of permanent or temporary business shutdowns, and restrictions are continuing in many parts of the country. Now, for 19 weeks in a row, new job losses have exceeded 1 million. In The US, the unemployment rate rose sharply from $4.40 \%$ to $14.70 \%$ in April, when Covid-19 began, and remains stubbornly high in the following months.

h111n19@soton.ac.uk 


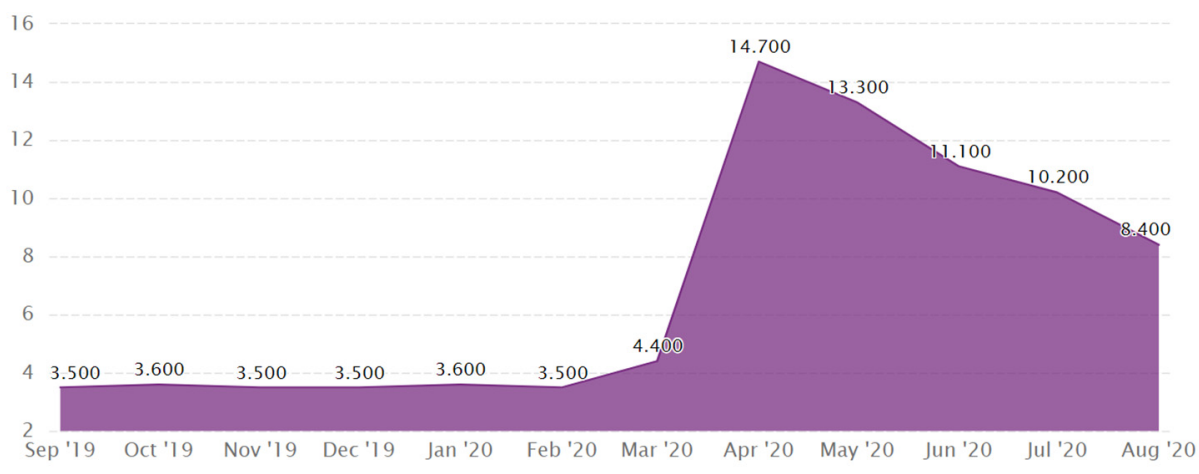

Figure1. Unemployed rate in the US [1]

As the condition of unemployment, many households lost the ability to repay their debts, resulting in more subprime loans. According to TransUnion, a consumer credit reporting agency "There has been a sharp increase in the number of 'financially distressed' accounts in certain credit products, particularly credit cards, auto loans, personal loans and mortgages. There are many aspects of 'financial distress', including late payments, frozen accounts, or late payments." [5] According to data, in April alone, about 14.7 million credit card accounts in the U.S. were in financial distress like this, accounting for $3.22 \%$ of all related accounts. In conclusion, a sharp rise in unemployment caused by the Covid-19 pandemic has affected household's ability to repay loans which may make many loans sub-prime.

\subsection{Despite increased risk exposure caused by Covid-19, the U.S. lending market continues to swell.}

The loans to the private sector still increased during the Covid-19 outbreak. At the same time, the outstanding debt of households and nonprofits continued to rise. As risk has increased, the base amounts of lending have an increasing trend, too. This means that in the future, American financial markets can be more constrained by the turmoil in the lending markets. U.S. financial markets could face greater risk if the lending system collapses with the large loan base.

\section{LOANS TO THE PRIVATE SECTOR*}

IN TRILLIONS, USD

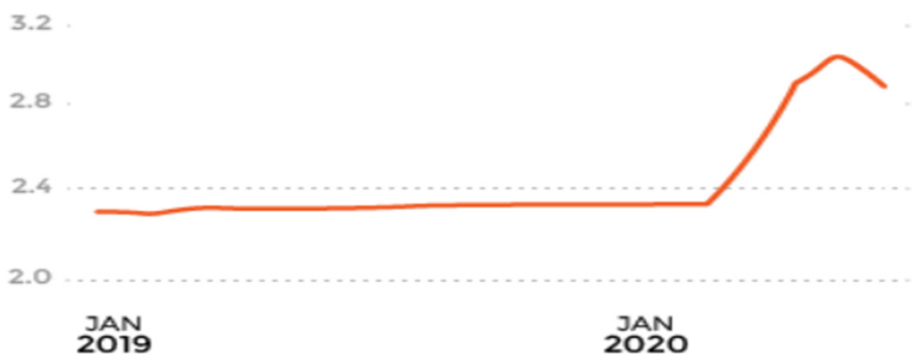

Figure2 Loans to the private sector in the US [2]

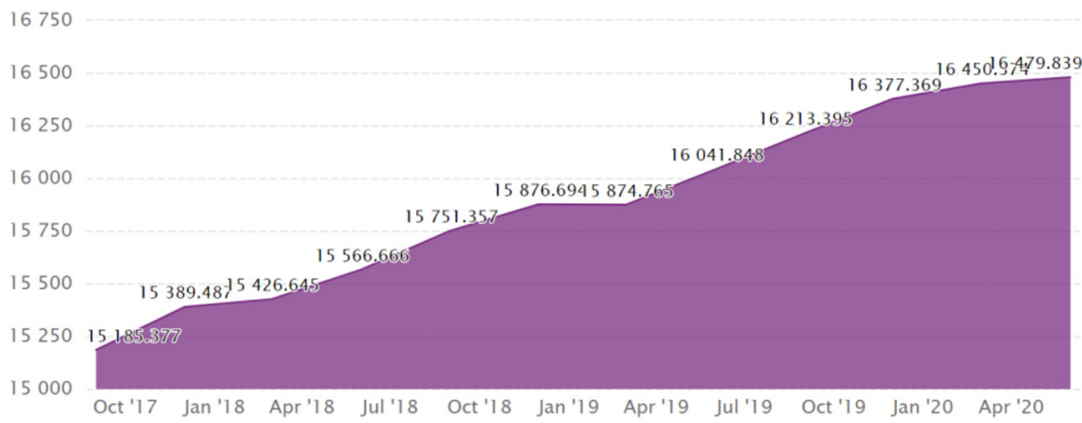

Figure3 Outstanding debt of families and nonprofit organizations (HO) in the US [3] 


\subsection{At the same time, the Covid-19 outbreak has had a big impact on the databases from which lenders can determine who is creditworthy.}

"To make matters worse, sorting through the confusion prompted by massive job losses and unprecedented federal intervention could take years for lenders as the industry struggles to compete in a market with wild swings in supply and demand. This means over the long term that lenders could increasingly be exposed to potential losses and limited in taking on new business while they grapple with who is creditworthy." [4] Taking auto market in the U.S. as an example, the credit crunch for subprime borrowers began in April which means there are lower approval rates for auto loans. The distribution of lending by lenders shifted to higher credit levels of lending. According to the data from Equifax, subprime consumers accounted for 8.8 percent of the market in May and June 2020, down from 14 percent in 2019. Because of the lack of information, subprime mortgage applications have become more difficult. In general, cash flows into the subprime market have become scarce because of the information asymmetry caused by Covid-19. It is harder for people to get loans from the subprime market because of this Covid-19 outbreak.

\section{Financial market coping strategies}

\subsection{In the short term, financial companies are under considerable pressure.}

In the long term, with the control of the epidemic, the market may experience recovery and retaliatory growth. In the face of the short-term impact of Covid-19 on the lending market, financial intermediaries in the financial market should actively change their strategies to deal with the potential crisis. Firstly, with the impact of the epidemic on offline businesses, most activities about loans will migrate from offline to online. Lending institutions should develop online services including postloan management and calling in loans. Secondly, the original database on lenders became less reliable in the event of an outbreak of Covid-19. Financial intermediaries have to establish a complete set of the data analysis system, through the key indicators monitoring such as accumulative total loans, borrowers' repayment ability changes and other related indicators. Then it carries on the real-time monitoring through the scientific and technological means, and gives the threshold warning for the key indicators. In case of unexpected situation, pressure output can be carried out through reporting approval and other measures to achieve risk control.

\section{Policy recommendations}

Since the global outbreak in March, the epidemic has affected the United States, China, Italy and other large economies. Pandemics such as Covid-19 have occurred repeatedly throughout human history. In 1974, the smallpox outbreak year, the MSCI index fell the most, reaching $27.57 \%$. However, the market may have fallen more because of the first oil shock in that year. So, on the whole, there was basically no global financial crisis simply caused by the epidemic. Although Covid-19 is unlikely to trigger a financial crisis like the one in 2008 caused by the real estate bubble, it has had an impact on subprime lending and even financial markets. To reverse the decline, national policy decisions are essential to revive markets.

In order to solve the existing or potential crisis caused by this outbreak of Covid-19, the first thing the government should do is to control the spread of this disease so as to achieve the goal of safe resumption of work. After the resumption of production, the unemployment rate can return to the normal level, and the people's ability to repay their loans will be guaranteed to some extent. Exposure to credit markets will become relatively low, reducing the likelihood of volatility. Taking Wuhan of China as an example, the closure of Wuhan city began on January 23, 2020 and lasted for 76 days until April 8, 2020. Up to now, Wuhan has basically resumed all economic activities. It turns out that short periods of lockdown are important for long-term economic activity in the future. The government has played an important role in controlling the spread of the disease including allocating resources and enforcing the closure of the city.

While halting the spread of the epidemic, reducing unemployment is also an important way to control the potential crisis. Only with financial resources can the debtors be assured of his ability to pay their debts. Firstly, the U.S. Department of Labor sets the minimum wage at $\$ 7.25$ an hour. However, under the condition of Covid-19, the government needs to temporarily lower the minimum wage to make sure more people are put to work. Secondly, the U.S. government can bring in foreign investment to help local people find jobs. Subsidies also can be given to domestic enterprises so that they can set up factories creating more jobs for their own people. When jobs are secured, loans are secured.

At the same time, economic policies are also essential as the government tries to control the outbreak. According to the Washington Post of March 25, 2020, "U.S. Senate leaders have reached a deal with the Trump Administration on a $\$ 2$ trillion economic stimulus package that will save the U.S. economy from the novel Coronavirus. The legislation is unprecedented in size and scope. The goal is to send $\$ 1,200$ in cash checks to many Americans, provide $\$ 367$ billion in loans to small businesses, and create a $\$ 500$ billion fund for industry, cities and states to pump money into the economy." [6] The unprecedented economic support from the U.S. government could be a huge help to the domestic economy. However, financial support for low-income people should not be given in large amounts at one time, but in small amounts over and over again. In this way, it is better for people to maintain basic economic activities including repaying their loans without making subsidies a one-time waste. 


\section{Conclusion}

In the case of the world being swept by the new epidemic, the United States has not been spared. At the time of high unemployment, the potential subprime mortgage crisis may come caused by Covid-19 in the US. Although this impact on subprime mortgage is unlikely to trigger a financial crisis in the United States, financial markets in the United States still had adverse reactions to the epidemic.

In this case, the U.S. loan companies should change their strategies, vigorously develop online services and improve the regulatory means after lending. At the same time, the U.S. government should also make corresponding policy decisions in response to the crisis. At the same time, governments should also respond to the crisis with policy decisions. The most important decision is to control the spread of the epidemic by means such as temporary closure of the city. With the outbreak under control and other means such as lowering the minimum wage to increase the employment rate, the resumption of work activities would return unemployment rate to normal levels to ensure the solvency of borrowers. In addition, government grants should be doled out in small amounts and repeatedly. Covid-19 is a shock to the U.S. financial lending market, and the government and financial lenders should adjust their strategies to deal with crises that have occurred or may occur.

\section{Acknowlegment}

First and foremost, I would like to express my respect and thanks to my professors, who have helped a lot in my study. Further, I would like to express my thanks to my friends. It was their encouragement that helped me finish my article.

\section{References}

1. CEICDATA 2020 https://www.ceicdata.com/zhhans/united-states/current-population-surveyunemployment-seasonally-adjusted/unemploymentsa

2. Visualcapitalis https://www.visualcapitalist.com/economic-impactof-covid-h1-2020/

3. CEICDATA $2020 \mathrm{https}: / / \mathrm{www} . c e i c d a t a . c o m / z h-$ hans/united-states/funds-by-sector-flows-andoutstanding-household-and-nonprofitorganizations/liabilities-outs-households-nonprofit-organizations-ho

4. Charniga, Jackie, "Consumer Credit Roiled by COVID-19; Subprime Borrowers Bear Brunt of Tighter Lending Standards." Automotive News 94.6942 (2020): 14. Web.

5. Michelle Black, "Coronavirus And Debt: Options To Consider If You Can't Afford To Pay Your Bills" Apr 29, 2020 https://www.forbes.com/sites/advisor/2020/04/29/c oronavirus-and-debt-options-to-consider-if-youcant-afford-to-pay-your-bills/?sh $=6 \mathrm{~cd} 87 \mathrm{ca} 01 \mathrm{dd} 4$

6. Erica Werner, Mike DeBonis, Paul Kane and Jeff Stein "Senate, White House reach \$2 trillion stimulus deal to blunt coronavirus fallout" The Washington Post https://www.washingtonpost.com/uspolicy/2020/03/24/trump-coronavirus-congresseconomic-stimulus/ 